\title{
Myocardial Postsystolic Shortening and Early Systolic Lengthening: Current Status and Future Directions
}

\author{
Philip Brainin
}

check for updates

Citation: Brainin, P. Myocardial Postsystolic Shortening and Early Systolic Lengthening: Current Status and Future Directions. Diagnostics 2021, 11, 1428. https://doi.org/ 10.3390 /diagnostics11081428

Academic Editor: Gaetano Nucifora

Received: 30 June 2021

Accepted: 4 August 2021

Published: 6 August 2021

Publisher's Note: MDPI stays neutral with regard to jurisdictional claims in published maps and institutional affiliations.

Copyright: (C) 2021 by the author. Licensee MDPI, Basel, Switzerland. This article is an open access article distributed under the terms and conditions of the Creative Commons Attribution (CC BY) license (https:// creativecommons.org/licenses/by/ $4.0 /)$.
Department of Cardiology, Herlev-Gentofte Hospital, Copenhagen University Hospital, DK-2900 Gentofte, Denmark; pjen0286@regionh.dk

\begin{abstract}
The concept of paradoxical myocardial deformation, commonly referred to as postsystolic shortening and early systolic lengthening, was originally described in the 1970s when assessed by invasive cardiac methods, such as ventriculograms, in patients with ischemia and animal experimental models. Today, novel tissue-based imaging technology has revealed that these phenomena occur far more frequently than first described. This article defines these deformational patterns, summarizes current knowledge about their existence and highlights the clinical potential associated with their understanding.
\end{abstract}

Keywords: deformation; postsystolic shortening; early systolic lengthening; speckle tracking echocardiography; clinical value

\section{Introduction}

In the past two decades, non-invasive imaging for assessment of cardiac function has become increasingly widespread in cardiology. In particular, the use of echocardiography, a key examination, has undergone rapid technological developments [1,2]. Traditionally, global and regional left ventricular function is often based on visual inspection of the cardiac wall segments. However, this is qualitative and subjective and often requires significant clinical experience to minimize intra- and inter-observer bias [3,4].

More recent tissue-based imaging technology has provided a more objective measure of cardiac function [5] and allows identification of specific deformational patterns, including postsystolic shortening (PSS) and early systolic lengthening (ESL) [6]. Today, PSS has been described in a plethora of studies, whereas ESL is more sparsely investigated. Both patterns represent a paradoxical deformation of the myocardial wall segments, and their identification may be useful for early recognition of ischemia, ischemic memory imaging and evaluating prognosis [6,7]. Considering the continuous interest in these patterns, an appraisal of the most recent literature on this topic is timely. The aim is to provide an overview of the contemporary knowledge on PSS and ESL and the potential clinical applicability of these patterns-spanning from normal myocardium to acute and chronic ischemia. Future directions and issues that need to be resolved to implement these features in a clinical setting will be highlighted.

\section{Physiological Deformation}

Is paradoxical deformation a feature of normal cardiac physiology? During ejection phase, it is estimated that approximately one-third of all wall segments in healthy individuals display PSS [8], defined as a delayed contraction after aortic valve closure (also known as postsystolic thickening when assessed by radial strain). In general, physiological PSS has a small magnitude and short duration [8,9]. By nature, timing of end-systole is crucial to accurately delineate PSS from systolic shortening. The same applies to ESL, defined as a lengthening in early systole (also referred to as systolic bulging), for which timing of end-diastole is important. Even though both deformation patterns do not contribute to the ejection of blood, their existence have been related to physiological reshaping of the 
left ventricle in healthy individuals $[8,10]$. A growing body of literature suggests that both patterns in a normal myocardium are influenced by age, sex and loading conditions [11]. Additionally, both deformation patterns are prone to changes in loading conditions, such that they are amplified with higher afterload and reduced with greater preload [12,13].

In clinical research, the following indices are widely used for quantification: postsystolic index ([peak postsystolic strain] - [end-systolic strain])/[peak postsystolic strain] and early systolic index: [peak positive systolic strain]/[end-systolic strain] (Figure 1A). Postsystolic time, defined as the interval from aortic valve closure to peak postsystolic strain, and duration of ESL, defined as time from Q-wave on the ECG to peak positive systolic strain, are also used. Throughout the last decades, several imaging methods have been used to quantify both patterns, involving invasive methods (ventriculograms, sonomicrometry) $[14,15]$ and non-invasive methods (strain-rate, tissue Doppler imaging, speckle tracking) (Figure 2A-E).

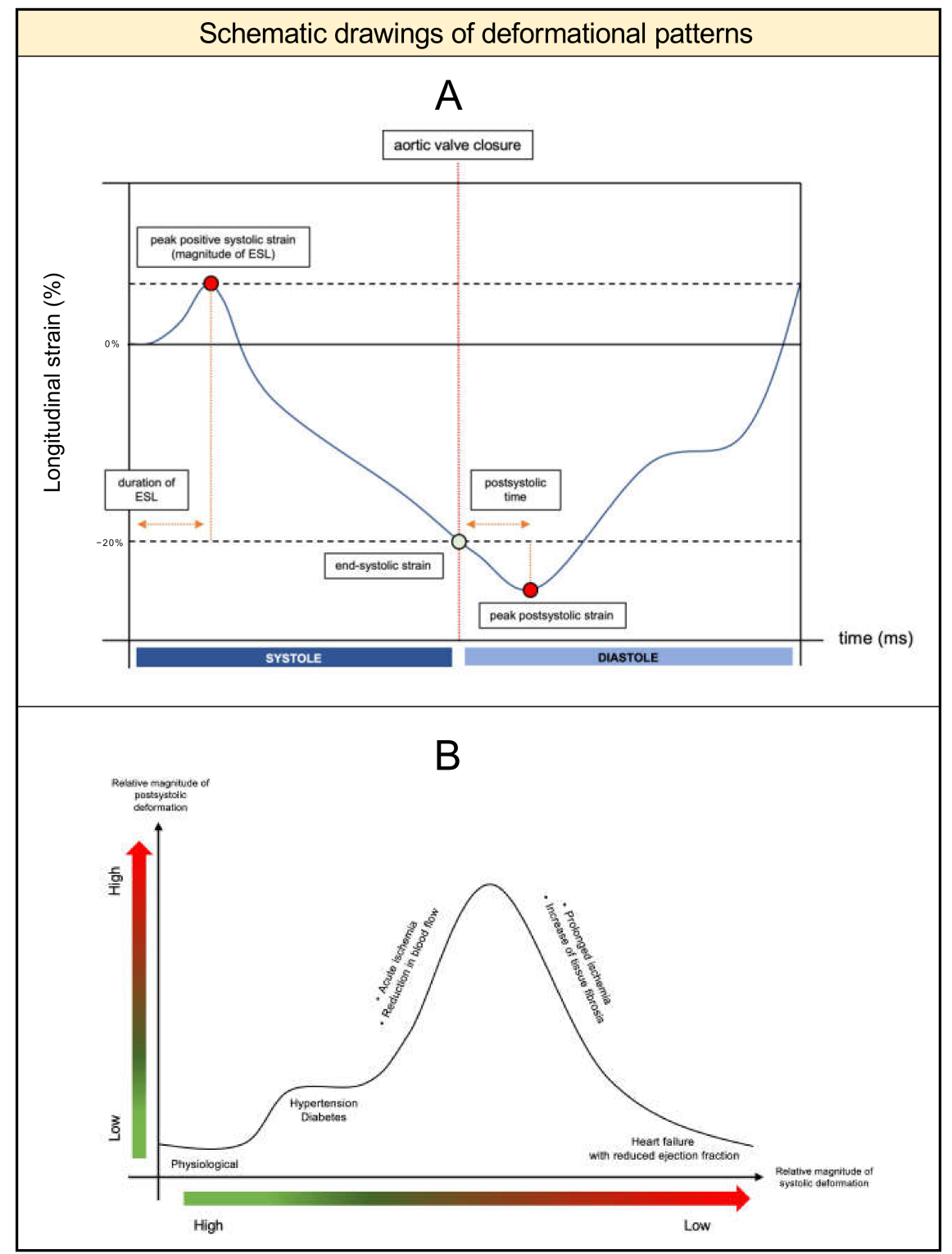

Figure 1. Longitudinal speckle tracking profile and suggested natural history of postsystolic shortening. Legend: (A): Schematic drawing of longitudinal speckle tracking profile displaying early systolic lengthening and postsystolic shortening as indicated with red dots. (B): Suggested natural history of postsystolic shortening. Relative magnitude of postsystolic shortening throughout different populations as a function of relative magnitude of systolic deformation. ESL: early systolic lengthening. 


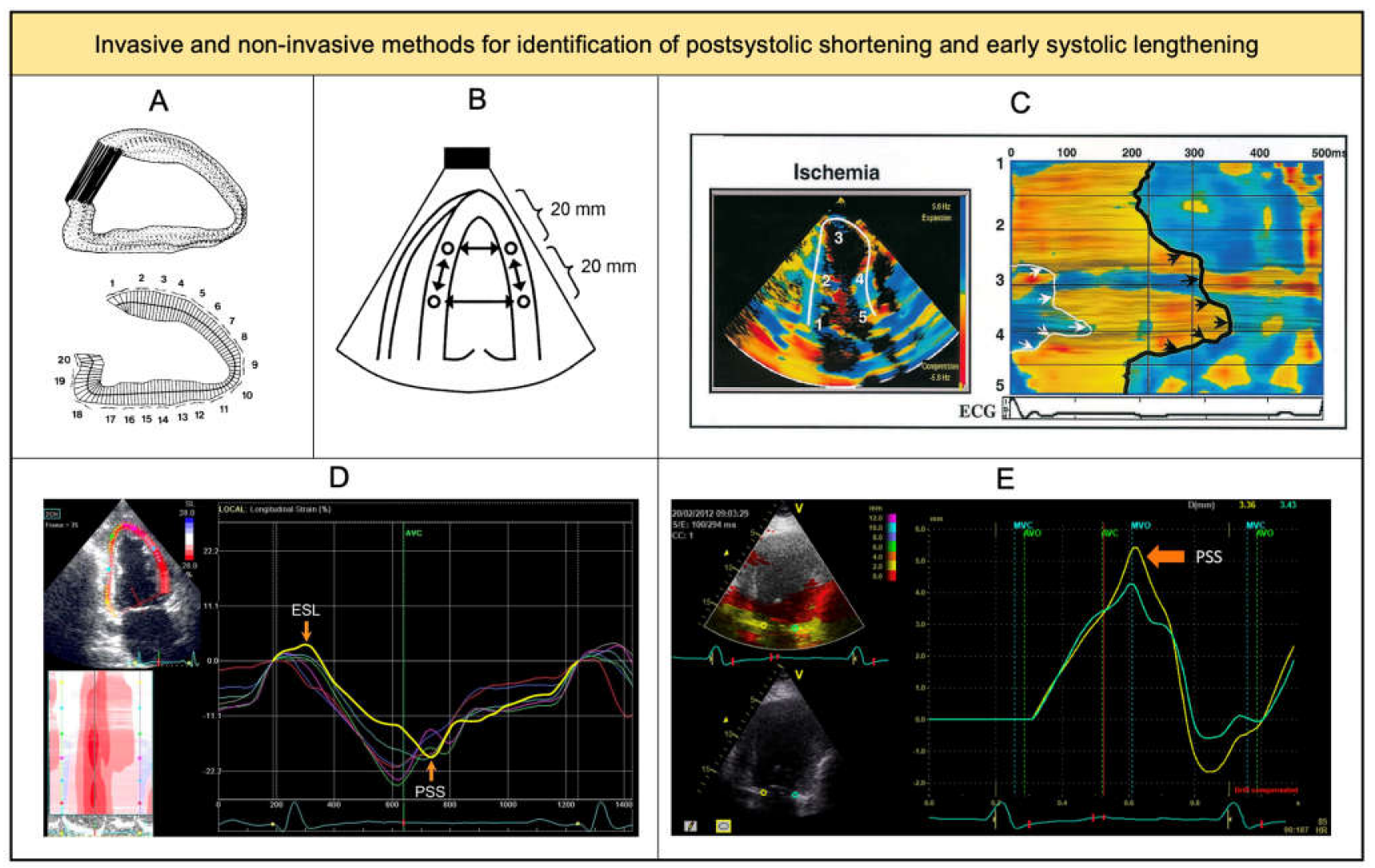

Figure 2. Invasive and non-invasive methods for assessing deformation patterns. Legend: (A) Ventriculogram depicting the centerline method for assessing wall motion. (B) Circles in the myocardial walls indicate embedded ultrasonic crystals to determine segmental length during the cardiac cycle. (C) Strain rate map during ischemia, where black arrows indicate postsystolic shortening and white arrows indicate delayed systolic shortening. (D) Longitudinal speckle tracking profile showing early systolic lengthening and postsystolic shortening. (E) Tissue Doppler imaging of longitudinal displacement of the mitral valve annulus showing postsystolic shortening. (A-C) are reprinted from Hosokawa et al. [14], Amundsen et al. [15] and Pislaru et al. [16] with permission the American College of Cardiology (Elsevier). (D) is reprinted from Asanuma et al. [6] with permission from the British Medical Journal Publishing Group. (E) is reprinted from Brainin et al. [17] with permission from Springer Nature.

\subsection{Conditions That Affect Deformation}

Multiple parameters affect myocardial deformation [18,19]. Intrinsic contractility determines the contractile force and deformation of each myocardial segment and is influenced by electrical activation [20] and tissue perfusion. Consequently, deformation patterns in the setting of bundle branch block and in pace-rhythms should be interpreted with caution. As myocardial segments are embedded in the walls of the ventricle, surrounding segments may employ external forces on each other and alter the deformation. External forces are caused by cavity pressure (preload/afterload), which determines wall stress and tension from neighboring segments [9]. This is mostly an issued related to tissue Doppler imaging, as speckle tracking theoretically is less affected by myocardial tethering. Elasticity, an essential component in tissue structure, is affected by fibrosis and relates directly to deformation. This was demonstrated in a study where PSS was associated with procollagen type 1 carboxyterminal propeptide, a marker of myocardial fibrosis [21]. When tissue elasticity is replaced by fibrosis, it leads to a gradual decline in deformation, up to the point where segments only move passively. Because deformation implies that elasticity to some degree is preserved, PSS and ESL have been coined as predictors of tissue viability [22-26]. Other parameters that affect deformation patterns are pharmacotherapy (dobutamine, beta-blockers) [27] and possibly also diabetes and hypertension [21,28]. 


\subsection{Proposed Underlying Mechanisms}

Although no consensus exists, there has been considerable interest in the mechanisms accounting for PSS. The most controversial topic is whether PSS represents active contraction or passive recoil. By assessing left ventricular pressure and segmental length loops before and after coronary stenosis and occlusion, Skulstad et al. concluded that dyskinetic segments display PSS by a passive mechanism, whereas akinetic and hypokinetic segments rely on active contraction [29]. Bijnens et al. argued that this method takes into account external forces acting upon the ischemic segments [27]. Thus, segmental length loops cannot be strictly used to answer this question. In support of active contraction, Lyseggen and colleagues implemented a lengthening-shortening ratio with the purpose of distinguishing active and viable segments from passive segments, albeit it was recognized that passive segments still can be viable [30,31]. By contrast, Claus et al. established a mathematical model and found that PSS during ischemia largely can be explained by passive recoil [32], a finding also supported by Akaishi et al. [33]. No studies have specifically addressed the underlying mechanisms of ESL.

\subsection{Association to Filling Pressure}

PSS may lead to abnormal intraventricular filling [12], subsequently delaying diastolic lengthening and contributing to increased left ventricular filling pressure. Studies have demonstrated how PSS correlates with echocardiographic indices of diastolic function such as E/A-ratio, E/e'-ratio and diastolic strain rate [11,21,34]. Likewise, PSS appears to be more pronounced in hypertensive patients compared with healthy individuals, which could be due to a greater risk of subclinical ischemic heart disease among hypertensives [21,34,35]. Whether PSS contributes to development of diastolic dysfunction remains uninvestigated.

\subsection{Phenotype of Paradoxical Deformation}

Presence of physiological PSS and ESL can complicate timely identification of pathological PSS and ESL. Similarly, it is difficult to assess PSS and ESL in already damaged and fibrotic myocardial tissue. Criteria to delineate physiological versus pathological PSS were proposed by Voigt et al. (Table 1) [8], and it was suggested that evaluating strain rate during the isovolumic relaxation time could be used for discrimination $[9,36]$. Regardless of this, the relative amount of PSS seems to increase across populations with a greater burden of cardiovascular diseases $[11,17,37,38]$. Similar approaches for differentiating ESL are encouraged in future clinical investigations.

Table 1. Criteria by Voigt et al. [8] to identify pathologic postsystolic shortening by strain derived from tissue Doppler imaging.

\section{Criteria}

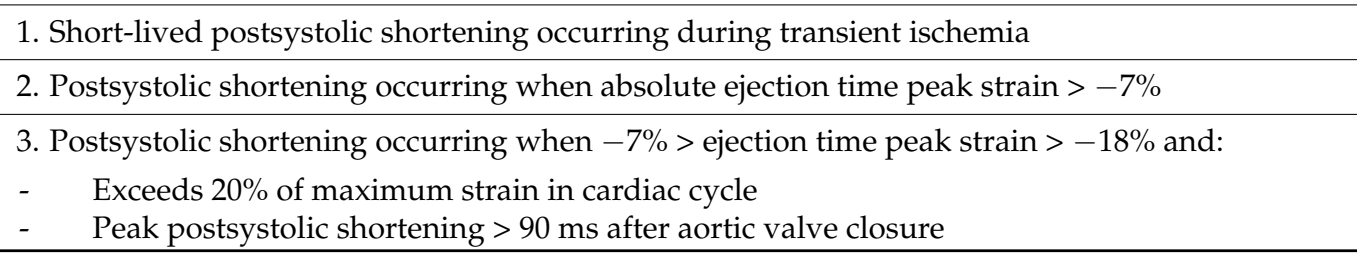

While pathological PSS and ESL commonly are seen as features of ischemic myocardium, it is noteworthy that they are also observed in non-ischemic heart disease, such as hypertrophic and dilated cardiomyopathy [39,40], Takotsubo cardiomyopathy [41], hypertension [21,34,35], aortic stenosis [42] and in electrical conduction delay [20,43,44]. Ring et al. showed that the presence of PSS correlates with the duration of the QRS complex [45]. In fact, it is regarded that these deformational patterns may be induced by any condition yielding an imbalance, or heterogeneity, between neighboring myocardial segments, irrespective of whether this is caused by ischemia, higher wall stress or delayed contraction. Thus, PSS and ESL are sensitive for detecting ischemia but offer little specificity. 


\section{Pathological Deformation}

\subsection{Evaluation in Acute Ischemia}

During acute ischemia, myocardial segments lengthen during early ejection phase (i.e., ESL), whereas unaffected segments continue to shorten. In general, this is accompanied by an overall decrease in systolic strain [46,47] and a concomitant increase in PSS [48-50] (Figure $3 \mathrm{~A}$ ). The magnitude of these changes is directly associated with the degree of stenosis and reduction in transmural blood flow [7,13,51-57]. During complete occlusion, overall deformation deteriorates; however, tethering to unaffected surrounding segments may still cause motion [32]. Upon reperfusion, both deformational patterns gradually diminish [55], although myocardial stunning can cause them to persist for a while [27]. In stunned segments with preserved elasticity, recovery of systolic deformation is paralleled by a concomitant decrease in PSS [58]. Thus, in a clinical setting, identification of PSS and ESL may be useful in patients with suspected ischemia $[16,59,60]$, and it is proposed that up to $80 \%$ of patients with coronary artery disease show PSS [8]. A recent study from our group linked PSS to coronary artery calcium score [61], indicating that recognition of PSS potentially may aid in the selection of patients referred for cardiac computed tomography. As of today, an abundant number of studies support that PSS possibly may be superior to conventional echocardiographic parameters and systolic strain for differentiating ischemic versus non-ischemic segments [50,62-65]. Far fewer studies have assessed the usefulness of ESL in acute ischemia. As opposed to regional longitudinal strain, which has only gained limited clinical use due to questionable reproducibility, recognition of regional deformational patterns, including PSS and ESL $[17,66]$, may be associated with localization of coronary occlusion and infarct site.

\subsection{Predictor of Recovery}

In terms of recovery, higher levels of PSS at baseline are associated with improved long-term systolic recovery $[14,23,68,69]$. Specifically, it was demonstrated that segments that showed PSS provoked during echocardiographic stress testing had a greater potential for recovery from revascularization [26,70,71]. For ESL, two studies found that the duration correlated with final infarct size and transmural extent of infarction as determined by magnetic resonance imaging [66,72]. Based on this, it is possible that deformational patterns contain useful information when assessed prior to revascularization. The clinical significance is that paradoxical deformation patterns possibly may guide the selection of patients who would benefit from revascularization procedures. Recovery is not only restricted to myocardial ischemia, as the presence of PSS is also associated with reverse remodeling and improved systolic function after long-term treatment with cardiac resynchronization therapy in heart failure patients $[73,74]$.

\subsection{Ischemic Memory Imaging}

When exposed to transient ischemia (seconds to minutes) and later re-perfused, abnormal deformation continues for a period of time despite normalization of blood flow (Figure 3B). The delayed appearance of abnormal deformation may be useful in situations where acute chest pain has resolved prior to arrival in the hospital and is referred to as ischemic memory imaging $[67,75,76]$. Studies have demonstrated that PSS and ESL have greater accuracy compared with systolic strain for identifying ischemic memory $[77,78]$. Because pathological PSS decreases over time, whereas physiological PSS remains constant, serial assessment is necessary in patients with transient ischemia [6]. Although ischemic memory imaging was introduced nearly a decade ago, reference values of PSS and ESL in this field are undetermined, and the time interval for reliable detection after ischemia is unclear. 


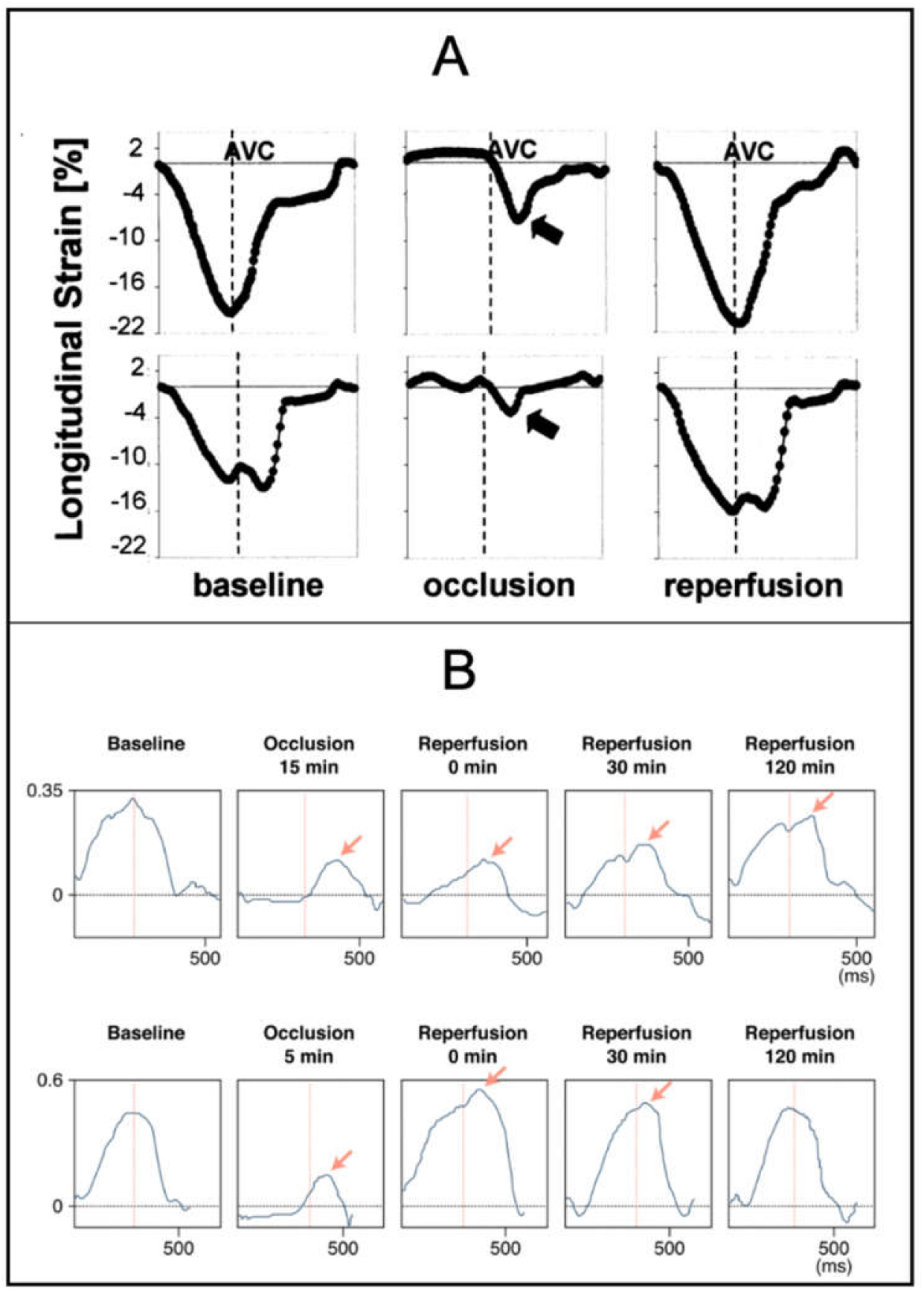

Figure 3. Deformation patterns during myocardial ischemia. Legend: (A) Longitudinal strain profiles in segment with normal wall motion (upper row) and segment with abnormal wall motion (lower row). Obtained before occlusion, 30 to $60 \mathrm{~s}$ after occlusion of LAD and $2 \mathrm{~min}$ after balloon reperfusion. The normal segment develops ESL and PSS after occlusion. The abnormal segment displays PSS at baseline, and the magnitude increases after occlusion. (B) Radial strain profiles of myocardial area exposed to $15 \mathrm{~min}$ (upper row) and $5 \mathrm{~min}$ (lower row) of coronary occlusion. Postsystolic thickening continues to appear after reperfusion in the segment exposed to $15 \mathrm{~min}$ of ischemia (indicating 'ischemic memory'), whereas it disappears in the segment exposed to $5 \mathrm{~min}$ of ischemia. (A,B) are reprinted from Kukulski et al. [50] and Asanuma et al. [67] with permission from the American College of Cardiology (Elsevier). LAD: left anterior descending artery, AVC: aortic valve closure. PSS: postsystolic shortening, ESL: early systolic lengthening. 


\subsection{Chronic Ischemia and Fibrosis}

Chronic ischemia leads to myocyte loss and fibrosis, which affects tissue elasticity and deformation [27]. While subendocardial fibrosis reduces systolic deformation and induces PSS and ESL, segments with transmural fibrosis display no deformation [27]. This happens because the extent of deformation is directly related to the degree of fibrosis. Individuals with heart failure and reduced ejection fraction can therefore exhibit values of PSS within the range of healthy persons, as demonstrated by Ring et al. [45] (proposed natural history of PSS is depicted in Figure 1B).

\subsection{Prognostic Value}

More recently, our research group has shown the ability of PSS and ESL to predict adverse cardiovascular events in a spectrum of populations $[17,37,38,69,79-83]$. It was demonstrated that both deformational patterns yield prognostic information beyond that of conventional echocardiographic parameters and systolic strain, ranging from the general population $[10,38]$ to persons with diabetes $[82,83]$ and acute ischemia $[17,69,79]$.

\section{Future Directions}

In the last two decades, the clinical utility of speckle tracking imaging has been studied extensively. Research has focused on standardization and solving inter-vendor differences, and today global longitudinal strain is one the most robust and reproducible strain parameters [84]. Considering this progress, new parameters are being studied, such as left atrial and right ventricular strain, and abnormal deformational patterns have attracted novel attention.

Even though assessment of PSS and ESL constitutes a niche within strain imaging, and their role in clinical practice still is undergoing development, they have been evaluated in a variety of study populations, mostly focusing on ischemia. Table 2 displays an overview of current research areas and clinical applicability. From a clinical perspective, being able to differentiate physiological from pathological PSS and ESL remains an important issue to resolve. Except for serial assessment, where relative changes are quantified, reference values in different populations need to be determined to advance and encourage clinicians to identify deformational patterns. This may pave the road for risk stratification models and for implementing assessment in clinical routine, in which echocardiography already constitutes a key examination. The introduction of three-dimensional echocardiography represents a new technology for strain imaging that has recently gained attention in clinical research. Precautions should be taken as to whether this imaging modality provides sufficient temporal and spatial resolution for accurately identifying such short-lived events as PSS and ESL [85].

Table 2. Research areas and potential clinical applicability of PSS and ESL.

\begin{tabular}{cccc}
\hline Acute Ischemia & Transient Ischemia & Recovery & Prognosis \\
\hline Tissue viability & & $\begin{array}{c}\text { Identification of stunned } \\
\text { myocardium }\end{array}$ & General population \\
Degree of stenosis & $\begin{array}{c}\text { Ischemic memory } \\
\text { imaging }\end{array}$ & $\begin{array}{c}\text { Benefit of } \\
\text { revascularization }\end{array}$ & Diabetes \\
$\begin{array}{c}\text { Coronary artery } \\
\text { calcium score }\end{array}$ & $\begin{array}{c}\text { Cardiac } \\
\text { resynchronization } \\
\text { therapy }\end{array}$ & Ischemia \\
& & Heart failure
\end{tabular}

Paradoxical deformation patterns are not solely restricted to the left ventricle. They also occur in the right ventricle, where deformation can extend beyond closure of the pulmonic valve. More specifically, this was observed in populations with increased right ventricular systolic pressure [86,87]. Given the more recent use of speckle tracking of the right ventricle [88], 
this represents a new localization for investigations of paradoxical deformation. Combined analysis of PSS and ESL have been proposed, including the lengthening-shortening ratio [30] and, more recently, the myocardial deformation index [78]. The rationale is that both patterns represent abnormality; yet, it remains to be determined if ESL always coexists in the presence of PSS and whether it is necessary to assess both patterns at the same time. PSS and ESL are influenced by loading conditions and should therefore be cautiously interpreted. A novel parameter, the myocardial work index (or global wasted work), which incorporates strain and blood pressure, may constitute a more solid approach to dealing with loading conditions, potentially making assessment of PSS and ESL by speckle tracking redundant. This should be investigated in future clinical studies.

At the present time a plethora of different echocardiographic indices exists, each reflecting different aspects of the cardiac cycle. Many of these are correlated and can cause unnecessary confusion. For clinical translation, there is a need to simplify the overabundance of parameters and develop risk models that take several measures into account at the same time. These risk models cannot replace conventional echocardiographic examinations, but they may help in assessing what the eye cannot see.

\section{Conclusions}

Analysis of myocardial strain has allowed detection of subtle abnormal deformation patterns, including PSS and ESL, that are difficult to detect visually and by conventional echocardiography. Assessment of these patterns may provide both diagnostic and prognostic information, ranging from the general population to acute and chronic ischemia and in patients undergoing cardiac resynchronization therapy. Even though research on this topic has recently expanded significantly, there are, as highlighted, several issues that still need to be resolved prior to implementing these patterns in clinical practice.

Funding: This research received no external funding.

Acknowledgments: Flemming Javier Olsen and Morten Hedetoft for critical revision of this manuscript.

Conflicts of Interest: The author reports no conflicts of interest.

\section{References}

1. Claus, P.; Omar, A.M.S.; Pedrizzetti, G.; Sengupta, P.P.; Nagel, E. Tissue Tracking Technology for Assessing Cardiac Mechanics: Principles, Normal Values, and Clinical Applications. JACC Cardiovasc. Imaging 2015, 8, 1444-1460. [CrossRef] [PubMed]

2. $\quad$ Lang, R.M.; Addetia, K.; Narang, A.; Mor-Avi, V. 3-Dimensional Echocardiography: Latest Developments and Future Directions. JACC Cardiovasc. Imaging 2018, 11, 1854-1878. [CrossRef]

3. Joyce, E. LVEF: Long-standing monarch of systolic dysfunction, buckling under the strain? Eur. J. Heart Fail. 2014, 16, 1270-1272. [CrossRef] [PubMed]

4. Badano, L.; Stoian, J.; Cervesato, E.; Bosimini, E.; Gentile, F.; Giannuzzi, P.; Heyman, J.; Lucci, D.; Maggioni, A.P.; Piazza, R.; et al. Reproducibility of wall motion score and its correlation with left ventricular ejection fraction in patients with acute myocardial infarction. Am. J. Cardiol. 1996, 78, 855-858. [CrossRef]

5. Shah, A.M.; Solomon, S.D. Myocardial deformation imaging: Current status and future directions. Circulation 2012, 125. [CrossRef] [PubMed]

6. Asanuma, T.; Nakatani, S. Myocardial ischaemia and post-systolic shortening. Heart 2015, 509-516. [CrossRef] [PubMed]

7. Smedsrud, M.K.; Sarvari, S.; Haugaa, K.H.; Gjesdal, O.; Orn, S.; Aaberge, L.; Smiseth, O.A.; Edvardsen, T. Duration of myocardial early systolic lengthening predicts the presence of significant coronary artery disease. J. Am. Coll. Cardiol. 2012, 60, 1086-1093. [CrossRef]

8. Voigt, J.U.; Lindenmeier, G.; Exner, B.; Regenfus, M.; Werner, D.; Reulbach, U.; Nixdorff, U.; Flachskampf, F.A.; Daniel, W.G. Incidence and characteristics of segmental postsystolic longitudinal shortening in normal, acutely ischemic, and scarred myocardium. J. Am. Soc. Echocardiogr. 2003, 16, 415-423. [CrossRef]

9. Weidemann, F.; Broscheit, J.A.; Bijnens, B.; Claus, P.; Sutherland, G.R.; Voelker, W.; Ertl, G.; Strotmann, J.M. How to distinguish between ischemic and nonischemic postsystolic thickening: A strain rate imaging study. Ultrasound Med. Biol. 2006, 32, 53-59. [CrossRef] [PubMed]

10. Brainin, P.; Biering-Sørensen, S.R.; Møgelvang, R.; Jensen, J.S.; Biering-Sørensen, T. Duration of early systolic lengthening: Prognostic potential in the general population. Eur. Heart J. Cardiovasc. Imaging 2019, 1-8. [CrossRef] [PubMed] 
11. Brainin, P.; Biering-Sørensen, S.R.; Møgelvang, R.; de Knegt, M.C.; Olsen, F.J.; Galatius, S.; Gislason, G.H.; Jensen, J.S.; BieringSørensen, T. Post-systolic shortening: Normal values and association with validated echocardiographic and invasive measures of cardiac function. Int J. Cardiovasc. Imaging 2018. [CrossRef]

12. Urheim, S.; Edvardsen, T.; Steine, K.; Skulstad, H.; Lyseggen, E.; Rodevand, O.; Smiseth, O. Postsystolic shortening of ischemic myocardium: A mechanism of abnormal intraventricular filling. Am. J. Physiol. Heart Circ. Physiol. 2003, 284, H2343-H2350. [CrossRef] [PubMed]

13. Dalmas, S.; Wanigasekera, V.; Marsch, S.; Ryder, W.; Wong, L.; Foëx, P. The influence of preload on post-systolic shortening in ischeamic myocardium. Eur. J. Anaesthesiol. 1995, 12, 127-133. [PubMed]

14. Hosokawa, H.; Sheehan, F.H.; Suzuki, T. Measurement of postsystolic shortening to assess viability and predict recovery of left ventricular function after acute myocardial infarction. J. Am. Coll. Cardiol. 2000, 35, 1842-1849. [CrossRef]

15. Amundsen, B.H.; Helle-Valle, T.; Edvardsen, T.; Torp, H.; Crosby, J.; Lyseggen, E.; Støylen, A.; Ihlen, H.; Lima, J.A.C.; Smiseth, O.A.; et al. Noninvasive myocardial strain measurement by speckle tracking echocardiography: Validation against sonomicrometry and tagged magnetic resonance imaging. J. Am. Coll. Cardiol. 2006, 47, 789-793. [CrossRef]

16. Pislaru, C.; Belohlavek, M.; Bae, R.Y.; Abraham, T.P.; Greenleaf, J.F.; Seward, J.B. Regional asynchrony during acute myocardial ischemia quantified by ultrasound strain rate imaging. J. Am. Coll. Cardiol. 2001, 37, 1141-1148. [CrossRef]

17. Brainin, P.; Haahr-Pedersen, S.; Sengeløv, M.; Olsen, F.J.; Fritz-Hansen, T.; Jensen, J.S.; Biering-Sørensen, T. Presence of post-systolic shortening is an independent predictor of heart failure in patients following ST-segment elevation myocardial infarction. Int. J. Cardiovasc. Imaging 2017, 34, 751-760. [CrossRef]

18. Wiegner, A.W.; Allen, G.J.; Bing, O.H. Weak and strong myocardium in series: Implications for segmental dysfunction. Am. J. Physiol. Circ. Physiol. 1978, 235, H776-H783. [CrossRef] [PubMed]

19. Shimizu, G.; Wiegner, A.W.; Gaasch, W.H.; Conrad, C.H.; Cicogna, A.C.; Bing, O.H.L. Force patterns of hypoxic myocardium applied to oxygenated muscle preparations: Comparison with effects of regional ischemia on the contraction of non-ischemic myocardium. Cardiovasc. Res. 1996, 32, 1038-1046. [CrossRef]

20. Grines, C.L.; Bashore, T.M.; Harisios, B.; Olson, S.; Shafer, P.; Wooley, C.F. Functional Abnormalities in Isolated Left Bundle Branch Block: The Effect of Interventricular Asynchrony. Circulation 1989, 79, 845-853. [CrossRef]

21. Tsai, W.C.; Liu, Y.W.; Chen, J.Y.; Huang, Y.Y.; Shih, J.Y.; Tsai, L.M.; Chen, J.H. Postsystolic strain index is associated with delayed diastolic lengthening and diastolic dysfunction of the left ventricle in untreated hypertension. J. Hypertens. 2012, 30, 787-793. [CrossRef]

22. Kahyaoglu, M.; Gecmen, C.; Candan, O.; İzgi, I.A.; Kirma, C. The duration of early systolic lengthening may predict ischemia from scar tissue in patients with chronic coronary total occlusion lesions. Int. J. Cardiovasc. Imaging 2019, 35, 1823-1829. [CrossRef] [PubMed]

23. Eek, C.; Grenne, B.; Brunvand, H.; Aakhus, S.; Endresen, K.; Smiseth, O.A.; Edvardsen, T.; Skulstad, H. Postsystolic shortening is a strong predictor of recovery of systolic function in patients with non-ST-elevation myocardial infarction. Eur. J. Echocardiogr. 2011, 12, 483-489. [CrossRef] [PubMed]

24. Barletta, G.; Del Bene, R.; Lo Sapio, P.; Gallini, C.; Fantini, F. Post-ejection thickening as a marker of viable myocardium. An echocardiographic study in patients with chronic coronary artery disease. Basic Res. Cardiol. 1998, 93, 313-324. [CrossRef] [PubMed]

25. Song, J.K.; Song, J.M.; Kang, D.H.; Haluska, B.; Marwick, T.H. Postsystolic thickening detected by doppler myocardial imaging: A marker of viability or ischemia in patients with myocardial infarction. Clin. Cardiol. 2004, 27, 29-32. [CrossRef]

26. Fujimoto, H.; Honma, H.; Ohno, T.; Mizuno, K.; Kumita, S. Longitudinal Doppler strain measurement for assessment of damaged and/or hibernating myocardium by dobutamine stress echocardiography in patients with old myocardial infarction. J. Cardiol. 2010, 55, 309-316. [CrossRef] [PubMed]

27. Bijnens, B.; Claus, P.; Weidemann, F.; Strotmann, J.; Sutherland, G.R. Investigating cardiac function using motion and deformation analysis in the setting of coronary artery disease. Circulation 2007, 116, 2453-2464. [CrossRef] [PubMed]

28. Nakai, H.; Takeuchi, M.; Nishikage, T.; Lang, R.M.; Otsuji, Y. Subclinical left ventricular dysfunction in asymptomatic diabetic patients assessed by two-dimensional speckle tracking echocardiography: Correlation with diabetic duration. Eur. J. Echocardiogr. 2009, 10, 926-932. [CrossRef] [PubMed]

29. Skulstad, H.; Edvardsen, T.; Urheim, S.; Rabben, S.I.; Stugaard, M.; Lyseggen, E.; Ihlen, H.; Smiseth, O.A. Postsystolic shortening in ischemic myocardium: Active contraction or passive recoil? Circulation 2002, 106, 718-724. [CrossRef]

30. Lyseggen, E.; Vartdal, T.; Remme, E.W.; Helle-Valle, T.; Pettersen, E.; Opdahl, A.; Edvardsen, T.; Smiseth, O.A. A novel echocardiographic marker of end systole in the ischemic left ventricle: "tug of war" sign. Am. J. Physiol. Hear. Circ. Physiol. 2009, 296, H645-H654. [CrossRef]

31. Lyseggen, E.; Skulstad, H.; Helle-Valle, T.; Vartdal, T.; Urheim, S.; Rabben, S.I.; Opdahl, A.; Ihlen, H.; Smiseth, O.A. Myocardial strain analysis in acute coronary occlusion: A tool to assess myocardial viability and reperfusion. Circulation 2005, 112, 3901-3910. [CrossRef]

32. Claus, P.; Weidemann, F.; Dommke, C.; Bito, V.; Heinzel, F.R.; D’hooge, J.; Sipido, K.R.; Sutherland, G.R.; Bijnens, B. Mechanisms of postsystolic thickening in ischemic myocardium: Mathematical modelling and comparison with experimental ischemic substrates. Ultrasound Med. Biol. 2007, 33, 1963-1970. [CrossRef] [PubMed] 
33. Akaishi, M.; Weintraub, W.S.; Schneider, R.M.; Klein, L.W.; Agarwal, J.B.; Helfant, R.H. Analysis of systolic bulging: Mechanical characteristics of acutely ischemic myocardium in the conscious dog. Circ. Res. 1986, 58, 209-217. [CrossRef] [PubMed]

34. Nogi, S.; Ito, T.; Kizawa, S.; Shimamoto, S.; Sohmiya, K.; Hoshiga, M.; Ishizaka, N. Association between Left Ventricular Postsystolic Shortening and Diastolic Relaxation in Asymptomatic Patients with Systemic Hypertension. Echocardiography 2016, 33, 216-222. [CrossRef] [PubMed]

35. Carlhäll, C.; Wranne, B.; Jurkevicius, R. Is left ventricular postsystolic long-axis shortening a marker for severity of hypertensive heart disease? Am. J. Cardiol. 2003, 91, 1490-1493. [CrossRef]

36. Pislaru, C.; Anagnostopoulos, P.C.; Seward, J.B.; Greenleaf, J.F.; Belohlavek, M. Higher myocardial strain rates duringisovolumic relaxation phase than during ejection characterize acutely ischemic myocardium. J. Am. Coll. Cardiol. 2002, 40, 1487-1494. [CrossRef]

37. Brainin, P.; Skaarup, K.G.; Iversen, A.Z.; Jørgensen, P.G.; Platz, E.; Jensen, J.S.; Biering-Sørensen, T. Post-systolic shortening predicts heart failure following acute coronary syndrome. Int. J. Cardiol. 2019, 276, 191-197. [CrossRef] [PubMed]

38. Brainin, P.; Biering-Sørensen, S.R.; Møgelvang, R.; Søgaard, P.; Jensen, J.S.; Biering-Sørensen, T. Postsystolic Shortening by Speckle Tracking Echocardiography Is an Independent Predictor of Cardiovascular Events and Mortality in the General Population. J. Am. Heart Assoc. 2018, 7. [CrossRef] [PubMed]

39. Podroužková, H.; Meluzín, J.; Hude, P.; Krejčí, J.; Špinarová, L.; Vítovec, J. Post-systolic shortening influences early diastolic filling in patients with dilated cardiomyopathy. Cor Vasa 2012, 54, 62-67. [CrossRef]

40. Yuan, J.; Chen, S.; Qiao, S.; Duan, F.; Zhang, J.; Wang, H. Characteristics of myocardial postsystolic shortening in patients with symptomatic hypertrophic obstructive cardiomyopathy before and half a year after alcohol septal ablation assessed by speckle tracking echocardiography. PLoS ONE 2014, 9, 1-8. [CrossRef]

41. Sato, H.; Yoshitomi, H.; Watanabe, N.; Adachi, T.; Ito, S.; Yamaguchi, K.; Tanabe, K. Visually confirmed post-systolic shortening during the recovery period in four cases of Takotsubo cardiomyopathy. J. Echocardiogr. 2014, 12, 159-161. [CrossRef] [PubMed]

42. Villari, B.; Vassalli, G.; Betocchi, S.; Briguori, C.; Chiariello, M.; Hess, O.M. Normalization of left ventricular nonuniformity late after valve replacement for aortic stenosis. Am. J. Cardiol. 1996, 78, 66-71. [CrossRef]

43. Citro, R.; Galderisi, M.; Guarini, P.; Cicala, S.; Mattioli, D.; Bianco, A.; de Divitiis, O.; Gregorio, G. Left bundle branch block with and without coronary artery disease: Which value for a tissue Doppler-derived post-systolic motion? Ital. Hear. J. 2003, 4, 706-712.

44. Galderisi, M.; Cicala, S.; Sangiorgi, G.; Caso, P.; De Divitiis, O. Tissue Doppler-derived postsystolic motion in a patient with left bundle branch block: A sign of myocardial wall asynchrony. Echocardiography 2002, 19, 79-81. [CrossRef] [PubMed]

45. Ring, M.; Persson, H.; Mejhert, M.; Edner, M. Post-systolic motion in patients with heart failure-A marker of left ventricular dyssynchrony? Eur. J. Echocardiogr. 2007, 8, 352-359. [CrossRef]

46. Jamal, F.; Kukulski, T.; Strotmann, J.; Szilard, M.; D’hooge, J.; Bijnens, B.; Rademakers, F.; Hatle, L.; De Scheerder, I.; Sutherland, G.R. Quantification of the spectrum of changes in regional myocardial function during acute ischemia in closed chest pigs: An ultrasonic strain rate and strain study. J. Am. Soc. Echocardiogr. 2001, 14, 874-884. [CrossRef]

47. Okuda, K.; Asanuma, T.; Hirano, T.; Masuda, K.; Otani, K.; Ishikura, F.; Beppu, S. Impact of the Coronary Flow Reduction at Rest on Myocardial Perfusion and Functional Indices Derived from Myocardial Contrast and Strain Echocardiography. J. Am. Soc. Echocardiogr. 2006, 19, 781-787. [CrossRef]

48. Brown, M.A.; Norris, R.M.; Takayama, M.; White, H.D. Post-systolic shortening a marker of potential for early recovery of acutely ischaemic myocardium in the dog. Cardiovasc. Res. 1987, 21, 703-716. [CrossRef]

49. Tennant, J.; Wiggers, C. The effect of coronary occlusion on myocardial contraction. Am. J. Physiol. 1935, 112, 351-361. [CrossRef]

50. Kukulski, T.; Jamal, F.; Herbots, L.; D’hooge, J.; Bijnens, B.; Hatle, L.; De Scheerder, I.; Sutherland, G.R. Identification of acutely ischemic myocardium using ultrasonic strain measurements: A clinical study in patients undergoing coronary angioplasty. J. Am. Coll. Cardiol. 2003, 41, 810-819. [CrossRef]

51. Minamisawa, M.; Koyama, J.; Kozuka, A.; Miura, T.; Saigusa, T.; Ebisawa, S.; Motoki, H.; Okada, A.; Ikeda, U.; Kuwahara, K. Duration of myocardial early systolic lengthening for diagnosis of coronary artery disease. Open Hear. 2018, 5, 1-9. [CrossRef] [PubMed]

52. Brainin, P.; Hoffmann, S.; Fritz-Hansen, T.; Olsen, F.J.; Jensen, J.S.; Biering-Sørensen, T. Usefulness of Postsystolic Shortening to Diagnose Coronary Artery Disease and Predict Future Cardiovascular Events in Stable Angina Pectoris. J. Am. Soc. Echocardiogr. 2018, 31, 870-879.e3. [CrossRef]

53. Ishii, K.; Imai, M.; Suyama, T.; Maenaka, M.; Nagai, T.; Kawanami, M.; Seino, Y. Exercise-Induced Post-Ischemic Left Ventricular Delayed Relaxation or Diastolic Stunning. Is it a Reliable Marker in Detecting Coronary Artery Disease? J. Am. Coll. Cardiol. 2009, 53, 698-705. [CrossRef] [PubMed]

54. Takayama, M.; Norris, R.M.; Brown, M.A.; Armiger, L.C.; Rivers, J.T.; White, H.D. Postsystolic shortening of acutely ischemic canine myocardium predicts early and late recovery of function after coronary artery reperfusion. Circulation 1988, 78, 994-1007. [CrossRef] [PubMed]

55. Leone, B.J.; Norris, R.M.; Safwat, A.; Foëx, P.; Ryder, W.A. Effects of progressive myocardial ischaemia on systolic function, diastolic dysfunction, and load dependent relaxation. Cardiovasc. Res. 1992, 26, 422-429. [CrossRef] [PubMed] 
56. Kanzaki, Y.; Yamauchi, Y.; Morita, H.; Hayashi, M.; Komori, T.; Ukimura, A.; Ishizaka, N. Presence of postsystolic shortening increases the likelihood of coronary artery disease: A rest electrocardiography-gated myocardial perfusion SPECT study. J. Nucl. Med. 2015, 56, 1889-1894. [CrossRef] [PubMed]

57. Huttin, O.; Marie, P.Y.; Benichou, M.; Bozec, E.; Lemoine, S.; Mandry, D.; Juillière, Y.; Sadoul, N.; Micard, E.; Duarte, K.; et al. Temporal deformation pattern in acute and late phases of ST-elevation myocardial infarction: Incremental value of longitudinal post-systolic strain to assess myocardial viability. Clin. Res. Cardiol. 2016, 105, 815-826. [CrossRef]

58. Monnet, X.; Lucats, L.; Colin, P.; Derumeaux, G.; Dubois-Rande, J.L.; Hittinger, L.; Ghaleh, B.; Berdeaux, A. Reduction in postsystolic wall thickening during late preconditioning. Am. J. Physiol. Hear. Circ. Physiol. 2007, 292, 158-164. [CrossRef]

59. Masuda, K.; Asanuma, T.; Taniguchi, A.; Uranishi, A.; Ishikura, F.; Beppu, S. Assessment of Dyssynchronous Wall Motion During Acute Myocardial Ischemia Using Velocity Vector Imaging. JACC Cardiovasc. Imaging 2008, 1, 210-220. [CrossRef] [PubMed]

60. Belohlavek, M.; Pislaru, C.; Bae, R.; Greenleaf, J.; Seward, J. Real-time strain rate echocardiographic imaging: Temporal and spatial analysis of postsystolic compression in acutely ischemic myocardium. J. Am. Soc. Echocardiogr. 2001, 14, 360-369. [CrossRef] [PubMed]

61. Brainin, P.; Olsen, F.J.; Lassen, M.C.H.; Bech, J.; Claggett, B.; Fritz-Hansen, T.; Folke, F.; Gislason, G.H.; Biering-Sørensen, T. Postsystolic shortening on echocardiography as a gateway to cardiac computed tomography in patients with suspected stable angina pectoris. Int. J. Cardiovasc. Imaging 2020, 36, 309-316. [CrossRef]

62. Celutkiene, J.; Sutherland, G.R.; Laucevicius, A.; Zakarkaite, D.; Rudys, A.; Grabauskiene, V. Is post-systolic motion the optimal ultrasound parameter to detect induced ischaemia during dobutamine stress echocardiography? Eur. Heart J. 2004, 25, $932-942$. [CrossRef] [PubMed]

63. Voigt, J.U.; Exner, B.; Schmiedehausen, K.; Huchzermeyer, C.; Reulbach, U.; Nixdorff, U.; Platsch, G.; Kuwert, T.; Daniel, W.G.; Flachskampf, F.A. Strain-rate imaging during dobutamine stress echocardiography provides objective evidence of inducible ischemia. Circulation 2003, 107, 2120-2126. [CrossRef] [PubMed]

64. Onishi, T.; Uematsu, M.; Watanabe, T.; Fujita, M.; Awata, M.; Iida, O.; Sera, F.; Hirano, Y.; Nanto, S.; Nagata, S. Objective interpretation of dobutamine stress echocardiography by diastolic dyssynchrony imaging: A practical approach. J. Am. Soc. Echocardiogr. 2010, 23, 1103-1108. [CrossRef] [PubMed]

65. Ingul, C.B.; Stoylen, A.; Slordahl, S.A.; Wiseth, R.; Burgess, M.; Marwick, T.H. Automated Analysis of Myocardial Deformation at Dobutamine Stress Echocardiography. An Angiographic Validation. J. Am. Coll. Cardiol. 2007, 49, 1651-1659. [CrossRef] [PubMed]

66. Vartdal, T.; Pettersen, E.; Helle-Valle, T.; Lyseggen, E.; Andersen, K.; Smith, H.J.; Aaberge, L.; Smiseth, O.A.; Edvardsen, T. Identification of viable myocardium in acute anterior infarction using duration of systolic lengthening by tissue doppler strain: A preliminary study. J. Am. Soc. Echocardiogr. 2012, 25, 718-725. [CrossRef] [PubMed]

67. Asanuma, T.; Uranishi, A.; Masuda, K.; Ishikura, F.; Beppu, S.; Nakatani, S. Assessment of myocardial ischemic memory using persistence of post-systolic thickening after recovery from ischemia. JACC Cardiovasc. Imaging 2009, 2, 1253-1261. [CrossRef] [PubMed]

68. Hanekom, L.; Jenkins, C.; Jeffries, L.; Case, C.; Mundy, J.; Hawley, C.; Marwick, T.H. Incremental value of strain rate analysis as an adjunct to wall-motion scoring for assessment of myocardial viability by dobutamine echocardiography: A follow-up study after revascularization. Circulation 2005, 112, 3892-3900. [CrossRef] [PubMed]

69. Hsiao, J.F.; Pan, K.L.; Chu, C.M.; Chang, S.T.; Chung, C.M.; Hsu, J.-T. Usefulness of serial post-systolic shortening by speckle tracking echocardiography to predict major adverse cardiovascular events and segmental function improvement after acute myocardial infarction. PLoS ONE 2020, 15. [CrossRef] [PubMed]

70. Lee, Y.S.; Kim, K.S. Relationship between post-systolic motion during dobutamine stress echocardiography and functional recovery of myocardium after successful percutaneous coronary intervention. Korean Circ. J. 2009, 39, 477-481. [CrossRef] [PubMed]

71. Rose, J.; Schulz, R.; Martin, C.; Heusch, G. Post-ejection wall thickening as a marker of successful short term hibernation. Cardiovasc. Res. 1993, 27, 1306-1311. [CrossRef]

72. Zahid, W.; Eek, C.H.; Remme, E.W.; Skulstad, H.; Fosse, E.; Edvardsen, T. Early systolic lengthening may identify minimal myocardial damage in patients with non-ST-elevation acute coronary syndrome. Eur. Heart J. Cardiovasc. Imaging 2014, 15, 1152-1160. [CrossRef] [PubMed]

73. Sogaard, P.; Egeblad, H.; Kim, W.Y.; Jensen, H.K.; Pedersen, A.K.; Kristensen, B.; Mortensen, P.T. Tissue Doppler imaging predicts improved systolic performance and reversed left ventricular remodeling during long-term cardiac resynchronization therapy. $J$. Am. Coll. Cardiol. 2002, 40, 723-730. [CrossRef]

74. Yu, C.M.; Fung, J.W.H.; Zhang, Q.; Chan, C.K.; Chan, Y.S.; Lin, H.; Kum, L.C.C.; Kong, S.L.; Zhang, Y.; Sanderson, J.E. Tissue Doppler imaging is superior to strain rate imaging and postsystolic shortening on the prediction of reverse remodeling in both ischemic and nonischemic heart failure after cardiac resynchronization therapy. Circulation 2004, 110, 66-73. [CrossRef] [PubMed]

75. Sakurai, D.; Asanuma, T.; Masuda, K.; Hioki, A.; Nakatani, S. Myocardial layer-specific analysis of ischemic memory using speckle tracking echocardiography. Int. J. Cardiovasc. Imaging 2014, 30, 739-748. [CrossRef] [PubMed]

76. Hioki, A.; Asanuma, T.; Masuda, K.; Sakurai, D.; Nakatani, S. Detection of abnormal myocardial deformation during acute myocardial ischemia using three-dimensional speckle tracking echocardiography. J. Echocardiogr. 2020, 18, 57-66. [CrossRef] [PubMed] 
77. Asanuma, T.; Fukuta, Y.; Masuda, K.; Hioki, A.; Iwasaki, M.; Nakatani, S. Assessment of myocardial ischemic memory using speckle tracking echocardiography. JACC Cardiovasc. Imaging 2012, 5, 1-11. [CrossRef] [PubMed]

78. Kozuma, A.; Asanuma, T.; Masuda, K.; Adachi, H.; Minami, S.; Nakatani, S. Assessment of Myocardial Ischemic Memory Using Three-Dimensional Speckle-Tracking Echocardiography: A Novel Integrated Analysis of Early Systolic Lengthening and Postsystolic Shortening. J. Am. Soc. Echocardiogr. 2019, 1-10. [CrossRef]

79. Brainin, P.; Lindberg, S.; Olsen, F.J.; Pedersen, S.; Iversen, A.; Galatius, S.; Fritz-Hansen, T.; Gislason, G.; Søgaard, P.; Møgelvang, R.; et al. Early systolic lengthening by speckle tracking echocardiography predicts outcome after coronary artery bypass surgery. IJC Hear. Vasc. 2021, 34, 100799. [CrossRef]

80. Brainin, P.; Holm, A.E.; Sengeløv, M.; Jørgensen, P.G.; Bruun, N.E.; Schou, M.; Pedersen, S.; Fritz-Hansen, T.; Biering-Sørensen, T. The prognostic value of myocardial deformational patterns on all-cause mortality is modified by ischemic cardiomyopathy in patients with heart failure. Int. J. Cardiovasc. Imaging 2021. [CrossRef] [PubMed]

81. Brainin, P.; Haahr-Pedersen, S.; Olsen, F.J.; Holm, A.E.; Fritz-Hansen, T.; Jespersen, T.; Gislason, G.; Biering-Sørensen, T. Early Systolic Lengthening in Patients With ST-Segment-Elevation Myocardial Infarction: A Novel Predictor of Cardiovascular Events. J. Am. Heart Assoc. 2020, 9. [CrossRef] [PubMed]

82. Brainin, P.; Jensen, M.T.; Biering-Sørensen, T.; Møgelvang, R.; Fritz-Hansen, T.; Vilsbøll, T.; Rossing, P.; Jørgensen, P.G. Post-Systolic Shortening by Speckle Tracking Echocardiography Predicts Cardiac Events in Type 2 Diabetes. JACC Cardiovasc. Imaging 2020, 13, 1289-1291. [CrossRef] [PubMed]

83. Brainin, P.; Biering-Sørensen, T.; Jensen, M.T.; Møgelvang, R.; Fritz-Hansen, T.; Vilsbøll, T.; Rossing, P.; Jørgensen, P.G. Prognostic Value of Early Systolic Lengthening by Strain Imaging in Type 2 Diabetes. J. Am. Soc. Echocardiogr. 2021, 34, 127-135. [CrossRef] [PubMed]

84. Voigt, J.U.; Cvijic, M. 2- and 3-Dimensional Myocardial Strain in Cardiac Health and Disease. JACC Cardiovasc. Imaging 2019, 12, 1849-1863. [CrossRef]

85. Klaeboe, L.G.; Edvardsen, T. Echocardiographic assessment of left ventricular systolic function. J. Echocardiogr. 2019, 17, 10-16. [CrossRef] [PubMed]

86. Lumens, J.; Arts, T.; Tim Marcus, J.; Vonk-Noordegraaf, A.; Delhaas, T. Early-diastolic left ventricular lengthening implies pulmonary hypertension-induced right ventricular decompensation. Cardiovasc. Res. 2012, 96, 286-295. [CrossRef]

87. Hui, W.; Slorach, C.; Dragulescu, A.; Mertens, L.; Bijnens, B.; Friedberg, M.K. Mechanisms of right ventricular electromechanical dyssynchrony and mechanical ineffciency in children after repair of tetralogy of Fallot. Circ. Cardiovasc. Imaging 2014, 7, 610-618. [CrossRef] [PubMed]

88. Badano, L.P.; Muraru, D.; Parati, G.; Haugaa, K.; Voigt, J.U. How to do right ventricular strain. Eur. Heart J. Cardiovasc. Imaging 2020, 21, 825-827. [CrossRef] [PubMed] 